\title{
Mine landforms in Western Australia from dump to landform design: review, reflect and a future direction
}

HWB Lacy Mine Closure Management Services Pty Ltd, Australia

\begin{abstract}
Open cut mining in Western Australia (WA) has rapidly expanded in the last 60 years. Volumes moved per annum, once small, are now in excess of millions of tons per project. Dumping these volumes into stable formations a minimal distance from the pit as per model optimisation has proven a challenge, not only to the mining organisations, but to the regulators of those organisations, as optimal dumping design does not, in many cases, result in landforms that can be easily rehabilitated and closed.

Stable, safe, non-polluting, rehabilitated landforms that meet a final land use while meeting the demands of the community and regulators has required a steady change in approach leading to the industry taking responsibility via a suite of gradual improvements in waste characterisation, landform design and managed construction over the last four decades.

Commencing in 1989, the author became involved in landform rehabilitation for a multi-mine gold company, just as the Minerals and Energy Research Institute of Western Australia was conducting initial waste dump rehabilitation research in WA. Since that time, the author has consulted to many mines, and benchmarked mine closure widely across Australia and internationally, building capacity with mining professionals engaged in landform closure and rehabilitation by learning from successful, and not so successful, landform techniques applied at a wide variety of mine types.

A review across this short but dynamic period of landform construction and rehabilitation shows that there has been the steady application of a range of sciences to support landform construction, primarily with waste characterisation and block modelling to control mine waste dumping, the use of early computer aided design tools and erosion modelling tools. In time this advanced to a suite of one, two and three-dimensional Landform Evolution Modelling (LEM) software programmes that are used extensively.

However the review suggests that despite the industry's desire to proceed well, we are yet to take full advantage of the suite of geomorphic landform design tools available by application during mine planning, and that for some reason these have not been brought into common use in WA, unlike other major mining jurisdictions such as in USA.

We briefly discuss the evolution of landform design tools as we look to the future and further work on effective application of landform design, and as the industry looks to design in solutions to the landform problems of the past. In WA landforms constructed under the historical context of emerging knowledge provides the capacity to inform and learn by comparison of both historical and current closure and rehabilitation activities.

Landform rehabilitation is a time-dependent process. It's important that we reflect, review and determine a future direction while comparing the past and how our learnings can be applied to the challenges, we currently face in landform design, construction and closure.
\end{abstract}

Keywords: landforms, review, design, integrated waste landforms, geomorphic design, landform evolution model, landform design

\section{Introduction}

One of the major challenges associated with the expansion and development of large open cut mines over the last 60 years has been the successful rehabilitation and closure of mine waste landforms and tailing 
facilities. These mine features are the most substantial of the mining process and bring a raft of challenges relating to change in landscape function and visual amenity, and can leave environmental, economic and safety-related legacies as a result. Mining and mineral processing are significant waste generating processes, we produce great magnitudes of waste rock and tailings to win relatively small volumes of minerals. Mudd \& Boger (Franks 2015) estimated that, in 2011 alone, the global mining industry produced 7.1 billion tonnes of tailings and 55.9 billion tonnes of waste rock.

When we look at the matter of mine landforms in Western Australia (WA), and how the industry has responded, we have to consider this in the context of specific types of mine development through time. Apart from mine tailings, and mine shaft development waste left from the initial 100 years of mining (1860-1960), the bulk of mine waste movement commenced in the 1960s with iron ore development followed rapidly by bauxite and mineral sands. These minerals formed the bulk of the mining landform development to that time. However, neither bauxite nor mineral sands are the focus of this paper as the materials are effectively strip mined or hydraulically mined, and landform rehabilitation and management were quite rapidly researched and managed well primarily due to number of stakeholder issues, including proximity to local WA populations.

The 1970s saw rapidly expanding iron ore development, along with discovery and establishment of a number of nickel mines. In the 1980's renewed interest in gold due to the evolving carbon-in-pulp and carbon-inleach treatment technologies occurred and large low-grade open cut gold mines expanded rapidly (Lacy \& Grant 2018). Only the large landforms of the Pilbara bore a similarity to what was happening in the WA Goldfields, and the industries understanding of how to develop and manage landform formation from open cut mine waste was limited. This was unlike the open cut/cast dragline coal mining of eastern Australia, were the environment differs considerably being primarily in areas of higher rainfall, in productive agricultural areas, and far less isolated than the semi-arid deserts of WA.

During this period there was a growing awareness of the negative legacy of mining. Asbestos mining at Wittenoom in the 1940-1970's resulted in mesothelioma in miners, townsfolk and the indigenous community, and left some millions of tonnes of unconfined tails at the mine area post-closure. The operation had a disproportionate effect of malignant mesothelioma in the local Aboriginal population, when compared to world populations, with the highest mortality rate internationally (Franklin et al. 2016).

The 1960s saw sulphide rich tailing escape from the closed Big Bell gold mine, caused by recreational motor vehicles (from the nearby town of Cue), that destabilised the tailing facility, which then dispersed with considerable devastation over the surrounding countryside (William Lacy, pers. comm., 1993). In the gold mining centre of Kalgoorlie-Boulder a 'Dust Abatement Committee' was formed by the Agriculture Department and the local mine community in an attempt to manage massive dust storms from the Boulder tailings deposits, which then led to the initiation of some of WA's first mine waste rehabilitation studies (Fletcher et al. 1989; Jennings et al. 1993). We became aware of acid mine drainage (AMD) and spontaneous combustion, of significant concern in sulphide rich shales at the Pilbara iron mines of Mt Whaleback and Mt Tom Price. Impacts became apparent from early mines adjacent to the towns of Northampton, Southern Cross, Marvel Loch, Wiluna; which had either sulphide, or arsenic, rich ores, or sulphide roasters, at Wiluna or Kalgoorlie where in combination with nickel smelting, led to significant air quality issues for the local population in the regions adjacent.

In the $21^{\text {st }}$ Century the mining industry is far more challenged with the perception of many outside the sector that mining impacts threaten social cohesion, existing land uses, and the resources needed to maintain longterm land productivity (Abrahamsson; cited in Hancock 2019). If of inadequate quality, the post-closure mining landscape and its multiple landforms can conflict with society's values. The USA, for instance, with considerable mining legacies from early industrialisation $\left(19^{\text {th }}\right.$ to early $20^{\text {th }}$ century), on initiating the Surface Mining Control and Reclamation Act (Office of Surface Mining Reclamation and Enforcement 1977) had to address multiple questions never before considered (Berger 2003, p. 15). Berger points out that when the process of renewal of the landscape commenced in the western USA, it 'revealed many fault lines in society'. Questions in the physical, philosophical, technological, environmental, political, regulatory and ethical realm 
all came to the fore. In considering Berger's statement, I suspect that a process of renewal for our past and current mining landscape is a process yet to be done well in Australia.

\section{Review and reflect}

The development of mine landform management in WA, has been in response to the emergence of a large mining industry in Australia, particularly in the last 60 years. In parallel two organisations developed. The Australian Centre for Geomechanics (AGC), with its base in University of Western Australia, with prime interest in geotechnical and mine closure matters, and the Goldfields Environmental Management Group (GEMG) based in Kalgoorlie, with its interest in matters environmental. In 2018, the GEMG celebrated its 30th anniversary, providing the opportunity to conduct a brief review of the evolution of 'the influence of the GEMG on Landform Rehabilitation', with approximately 100 papers briefly reviewed across the subject areas of:

- Ecology, rehabilitation and monitoring processes.

- Topsoil, waste materials and applied science.

- Regulation, design, engineering, management and implementation (Lacy \& Grant 2018).

This process, and the contribution of the many AGC tailings, landform, and closure workshops, national and international since 1994, provided an effective source for this review of mine landforms. The AGC through the guidance of Professors Jewell, Fourie and Potvin instilled discipline to the development of quality conferences, and peer reviewed proceedings considered in this paper. Two of note; Rock Dumps 2008 and Mine Waste 2010, in particular focused on mine waste management and landforms at an international level (Fourie 2008; Fourie \& Jewell 2010).

Historically, the key design focus in open cut mining has been to minimise haulage costs; in many cases, the design and construction of landforms has involved only limited consideration of closure requirements and at best has been based on known technologies of the day provided as they evolved. A perspective on this evolution can be found described within early Australian government publications such as Landform Design for Closure (Environment Protection Agency 1998; Department of Industry Tourism and Resources 2006; Department of Industry, Innovation and Science 2016). Essentially 'learning as we go' has been the existing paradigm that mine rehabilitation and closure professionals have been challenged by over the last 40 years, but now reaching a point were incorporating closure in landform design is considered leading practice.

\subsection{0-1999: Awareness and challenge}

The 1980s and 1990s could be defined as a period of reactive responses more than proactive, as the industry initially had limited concern or knowledge in dump and landform management, and experience was nascent. Initially regulation was very basic or not evident, industry had to do little but build end-tip landforms, and walk away. However, landform design activity did commence i.e. in the 1980s, Walker at Mt Newman mine developed moonscaping for the very long slopes of iron ore waste (Walker 1987), and concurrently research was initiated in the Eastern Goldfields. At Meekatharra, the 1987 Haveluck dumps provided an example of a site of limited design or planned construction, but they were unique in that they appeared similar to the local landforms, and research indicated they rehabilitated reasonably well, blending into the landscape on the edge of the town (Lacy 1997).

Early innovation was soon followed by applied research commencing in 1985, 'Waste Management and Stabilisation' and 'Soil Handling and Management' (Petersen 1987; Burnside 1987). The initiation of mine rehabilitation research was encouraged by mining regulators and researchers from Department of Agriculture, and Universities Curtin, Murdoch, UWA, and Edith Cowan University soon engaged (Lindbeck 1992). International visitors came and spoke across a broad range of landform rehabilitation issues, legislation and liability in USA (Greenwald 1987), raising points regarding landform closure that pre-empted matters Australia has had to deal with in landform construction since. 
The rapid evolution of open cut mining in this period created the foundation for many forms of response, and subsequently, in the late 1980s, the Department of Mines and Energy initiated the employment of the first Environmental Mangers; Hugh Jones, followed by Keith Lindbeck, who collectively commenced a process of delivering guidance for landforms, developing regulation and setting appropriate tenement conditions for general mine rehabilitation. Original guidance called for a waste dump to blend into the surrounding landscape and to produce "stable and non-eroding surfaces in the long-term", with default designs " $4-5$ meter wide berms, at 10 meters vertical height, to be constructed with a water catchment and drainage channel, with $0.5 \%$ slope to rock lined waterways, to remove runoff from dump without erosion' (Department of Industry and Resources [DOIR] 1996; Jones 2008). The term 'safe stable and non-eroding' (Cannon 1996) particularly attracted comment, becoming 'safe stable and non-polluting' in the following decade carried forward to present day. The early Mine Waste Dump guidelines (DOIR 1996), including developing natural slopes i.e. convex-concave setting the scene for some 10-15 years of landform construction, conjecture, argument, challenge, research, experimentation and adaption.

Archer (1990), described early concepts of dump design and construction, while Law described processes to control erosion on waste dumps (Law 1992), and applied engineering of waste design using a block model and wireframe for 'Omega Island' a waste landform constructed on Lake Lefroy Kambalda was delivered (Woolard \& Valent 1990). Importantly in 1995 tropical cyclone 'Bobby' tested the built waste landforms by delivering a 1:250 - 1:350-year (ARI) rain event, and showed that water control on landforms and flood mitigation was a real issue for the industry. As the industry grappled with water management on landforms, we saw work on comprehensive rock drain and berm construction (Bradley 1996), and that the integration of waste dumps into the landscape was possible, and undertaken at sites like Wendy Gully mine - Broad Arrow Kalgoorlie (Loney 1998). During this period questions such as; whether or not to design to retain, or shed water on waste landforms, sheeting outer surfaces of waste dumps with topsoil mixed with laterite (known locally as Wiluna hardpan) to reduce erosion of the topsoil to facilitate water entry and create microhabitats and reducing wind drying effects were described and discussed (Lacy 1997, 1998).

The concept of co-disposal and other processes that integrate mine waste disposal were under consideration in WA, as was the concept of incorporating tailings storage facilities (TSF) within waste dumps, and became an initiative developed and described by Lane (1998) as a "tailings facility surrounded by a waste dump". On noticing that mine engineers had built dumps abutting the TSF at the Tuckabianna mine, Soil \& Rock Engineering took this concept through to building a circular TSF within a waste dump, the first being the Bronzewing mine, which was constructed in 1994 and was first presented as a valid initiative in Perth 1998 (Lane 1998), swiftly followed by Chalice and Mount McClure (TSF 4) mines in the late 1990s (Lacy \& Lane 2007).

Innovation continued and tested the existing landform design/guidelines in recognition that we were constructing landforms via rapid semi-controlled waste dumping, and mining, not civil, engineers and pit supervisors were working with rudimentary design tools and undertaking that process with little knowledge of the properties of the waste. The industry started to acknowledge that materials management was critical, particularly as we dealt with highly weathered highly dispersive and hypersaline paleo-channel wastes, that eroded and piped in quite spectacular fashion on many waste landforms. Skeletal and fine-grained topsoils were challenging to use and manage, with many sites dispersing eroded material of all kinds from the landforms. Nickel-laterite mining highly oxidised, weathered, and often dispersive material with large footprints commenced. In the Pilbara managing the AMD challenge continued, and Channel Iron Deposits, and landforms with river footprints were being developed.

As the McCrea's shales, found within the iron deposits of the Pilbara, spontaneously combusted and made those mines aware of AMD, a visiting regulator from USA, alerted us to that fact that WA had an undefined acid mine drainage risk through many of its metalliferous and mineral sands mines (Mohensen 1992). This decade saw a gradually evolving series of responses to all issues related to mine waste and soils by a suite of scientists (Stoneman 1994; Jasper 1994; Campbell 1994; Blandford 1994; Fahey 1994; Sholtz 1996; Osborne et al. 1996; Gilkes 1998) who rose to this challenge. 


\subsection{0-2010: Design and response}

This decade saw the new underground nickel and large nickel-laterite mines of considerable scale expand, whereas many oxide gold mines matured or exhausted known resources, then closed, went to care and maintenance, or continued as they became underground mines. Indeed, a decade of innovation commenced as applied science was brought to waste material management and landform design in WA. The 'Mine Closure' guide (Australian and New Zealand Minerals and Energy \& Minerals Council of Australia 2000) was produced setting goals for the industry in closure planning. Attention to landform design, construction and management improved, with increased emphasis on mine waste characterisation, rainfall simulation and erosion modelling (Loch \& Willgoose 2000; Landloch 2006) using the Water Erosion Prediction Project (WEPP) model, and the advent and application of the SIBERIA landform evolution model (LEM) (Willgoose 1989, 2005; Hancock et al. 2000, 2003). Plans such as the large waste rock decommissioning plan with up to 500 years of erosion modelling (McPhail \& Wilkinson 2004) demonstrated the application of SIBERIA prepared for the Argyle diamond mine.

A less prescriptive approach to landform regulation was initiated during this decade i.e. Enviro. Notes produced in 2001 (revised in 2009), provided greater leeway in design and a focus on erosion management was encouraged (Department of Mines and Petroleum 2001). Hence geomorphic concepts, the application of concave design slopes (Landloch 2006), longer contiguous slopes and removal of berms, and the use of armouring treatments, as was earlier reported in mid-1990s (Lacy 1997) become apparent, in new landforms, and in managing failed landforms (Swain et al. 2004). The application of multiple concave slopes, modified with laterite as an armour, finished with winged rippers and successfully applied at the closure of Mt McClure mine (Lacy \& Haymont 2006) provided a demonstration of this concave concept that could now be assessed through time.

By mid-decade, waste material characterisation and management was well underway, i.e. subjects as waste characterisation for optimal landforms (Jasper \& Braimbridge 2006), acid formation, sampling, procedures and testwork (Campbell 2006), and material characterisation evolving into AMD block models (Farrell 2006), and landforms were being constructed from designs generated and mined to block modelling plans of in situ ore and waste prior to mining (Russell 2008). Soil science and nutrient requirements came to the fore e.g. studies on phosphorus requirements of goldfields plants (Williams \& Pratt 2008) and topsoil organic carbon and nutrients for waste dump rehabilitation (Loch et al. 2008) were initiated and reported.

The integration of waste characterisation into landform design for low-risk and low-cost mine closure, was occurring in the field (Jasper et al. 2006), and with the increasing integration of the TSF design within the whole the mine planning process, opportunities for more efficient use of mine waste resources became apparent. By focusing on the mine waste scheduling process, it was possible to optimise the selective use and placement of the various mine waste materials for future embankment construction. Toward the end of this period a large-scale multi-faceted landform research programme was conducted at the Telfer mine. The trials studied the formation and rehabilitation of landforms structured in sympathy with the local geomorphic 'mesa' formations common to the area; consisting of hard laterite caps, concave rock armoured slopes, and became a well-advanced current example of learning from local landscape processes (Mifsud et al. 2010).

In 2001 the contained TSF concept that appeared in the previous decade, combining waste rock and tailings material within one structure, was named as an integrated waste landform (IWL) and defined as a landform "that integrates, in immediate proximity, different waste materials generated by a mining operation within multiple facilities in a single structure" (Sperring \& Lacy 2001). This definition of integration broadens the term so that not just tailings, but conceptually heap leaches, ROM pads, acid forming and intractable waste rock materials, mineralised waste, low-grade ore and landfill materials could all be considered as components that can make up an IWL. The concept, however, requires detailed planning, far more than the planning of a conventional above-ground TSF (Lane 2004). The concept of the IWL is perhaps the most practical and elegant example of landform innovation developed, and recently applied over this period in WA.

In 2006 tailings disposal and rehabilitation in WA (and Australia) was observed to have changed considerably over the previous 15 years (Lacy \& Barnes 2006), with a general move away from the typical paddock style, 
multi-celled, square shaped TSF, constructed by the upstream method using tailings, to circular TSFs built with continuous walls, or encapsulated by, waste rock walls as IWLs (Lane 2004; Lacy \& Barnes 2006). Another major initiative was the rapidly increased use of mined out areas (pits) for in-pit disposal of tailings (Lane 1998) in fact reducing the number and footprint of tailings landforms remaining across the mine landscape. Concurrently the increased use of the quite stable, very large footprint, Centrally Thickened Discharge (CTD) facilities, increased footprint. These utilised advancing thickened tailing and paste disposal technology (Jewell 2005), resulting in the largest individual TSF landform structures seen in WA, such as the 1400 -hectare Mt Keith CTD. With any of these structures yet to be rehabilitated and closed, the full cycle and economic evaluation of their use and final closure landform is still to be fully tested in WA.

We saw increasing standardisation of waste geochemistry and soil testing, particularly with concepts of store and release cover systems for prevention of AMD being introduced as a standard process through the industry. In 2008 Haymont \& Campbell (2008) tackled the complex subject of 'Soil Covers and Capping Monitoring Techniques' (based on extensive multi-site experience), for store and release covers, informed by an extensive literature review on the subject in relation to Australian conditions (Campbell 2004), and followed from Professor Ward Wilson who visited Australia during this decade, and 'regarded as the founder of store/release-cover systems, and barrier-cover systems' (Campbell 2004, p. 8) had considerable influence so nowadays these techniques are routinely employed, in a variety of forms, for mine waste containment worldwide.

\subsection{1-2019: Technology and refinement}

During this decade mining development peaked by 2013 , followed by a major downturn. Recovery gradually commencing in 2016 (Heaney 2016). Partially driven by the 2010 amendments to the WA Mining Act that required a mine closure plan to be submitted for approval of mining proposals (Department of Mines and Petroleum \& Environmental Protection Authority 2011), considerable improvements in waste characterisation, forward landform design and planning for closure, occurred during the period. A greater awareness has developed that methods used to mine ore could be used to mine and manage well characterised waste, with computing and block modelling applied to control designed landforms (Lacy \& Grant 2018), and mine software designers and engineers were seen to rapidly advance the use of tools such 'Dumpsolver', developed in the previous decades to optimise and structurally control landform dumping (Russell \& Lacy 2015).

Geographic information system and contour control technologies provided real-time guidance to machine operators, with highly localised survey management applied, hence 'unsupervised' control became a reality. Landform evolution erosion models were being applied to demonstrate that designs will be resilient, and enhanced survey and photographic control was more commercially and economically available through lidar and video systems mounted on drone platforms to evaluate stability, and monitor both erosion and development of revegetation on waste landforms.

Many scientists, i.e. Mabin (2014) providing an 'overview of the principals of geomorphic design, geomorphology and WA landscapes', Walsh (2014) on a 'progressive approach to growth medium mining' discussed strategically harvesting material during mining, and Howard (2014), discussed 'roughness and its influence on erosion of batters', show the range of areas of advancement and inquiry. Yet despite all this effort Ashby \& Van Etten (2016) in a review of 20 randomly selected WA goldmines (on care and maintenance), using spatial data - and imagery showed that rehabilitation appears to be sporadic with varying levels of rehabilitation success and many tailings facilities were often bare, some breached with releases, and evidence that waste landforms were also found to be releasing sediment into the environment (Ashby \& Van Etten 2016). Many authors (File et al. 2010; Beiha-Malen et al. 2012; Thompson \& Thompson 2012; Gregory et al. 2014) raised and consistently returned to the issue of appropriate processes to evaluate completion criteria, as many site closures do not result in landform sign off, and acceptable levels of closure remain challenging, suggesting that the Mining Resources Fund and the nascent Abandoned Mine Fund of WA (Bellamy 2016) two innovative regulatory instruments, will be heavily drawn upon well into the future. 
Adoption of geomorphic landform designs that sheds water as does the natural surrounding analogue environment (via drainage systems), rather than a hard engineering approach that utilises drop down structures and rocklined drains inserted into the mine waste, has become a more feasible and achievable process through the advances in survey control via geostationary satellites and global positioning, providing real-time survey control to the individual on ground earthmoving machine (Leidich et al. 2014). Supporting geomorphic adoption has been the development of LEM. Importantly the industry was starting to appreciate, primarily due to economics that a key principle developing a waste landform is to minimise both the cost of construction and the cost of closure, by getting it right first time (Jasper et al. 2012, p. 21).

LEM advanced considerably during this decade with Hancock and Willgoose (2017) report their use of SIBERIA in projects in Australia, Argentina, Canada, Namibia, Papua New Guinea, Tanzania and the United States, and the advancement of the software (Willgoose 2012). They also outlined its application by consultants globally and that it has the strongest scientific base for landform design in mine rehabilitation (Evans \& Riley 1994; Willgoose 1989; as cited in in Hancock et al. 2003). Other LEMs, such as CAESAR-Lisflood, can run at hourly time steps and can assess the effects of storm events on erosional stability. A new generation of soilscape models are also now available which incorporate both spatially variable hydrology, and soil material properties (Cohen 2009; Welivitiya 2016; as cited in Hancock \& Willgoose 2017).

Despite the years of improvements, Haymont (2018) suggested a note of caution on dependency on models. Who, based on experience in applying these concepts from erosion models, stated:

"Erosion modelling is an indicative tool which can help in the generation of more desirable shapes, and erosion minimisation, but that abstract numerical model outputs, should not be used as basis of design or for completion criteria'. Further to this 'that if the mining industry invested in rigorous studies, which accurately measure and calibrate field erosion against models over a long-time frame (20+ years), the use of erosion models might be used with greater confidence. Until that time these models should be approached with care, and always used as one of a number of informing lines of evidence to design final landforms which are stable in the long term."

However, it would be my contention that the very limited exposure in Australia to the full suite of 'design tools' effectively applied by experienced practitioners, has only just begun and that the functional design tools used extensively and successfully in other parts of the world (discussed further in Section 3), will bring confidence in the application of models via matching with the best design tool application.

We close our progress review for WA, by noting that the WA Iron Ore Division of BHP recently provided a case study on their approach to closure and rehabilitation governance, Delivering Closure Landforms Through Mine Planning in Western Australia. Published in the internationally distributed Integrated Mine Closure: Good Practice Guide, that showcases their guiding principles for the WA iron mines, coupled with waste and landform design knowledge through a process of "Life of Mine planning to bring optimal production and closure outcomes" (International Council of Mining and Metals 2019, p. 13), and in essence reflects how far companies in the WA mining industry have advanced.

\subsection{Landforms 1980-2008: Benchmark sites}

We can learn from both historical, and current, closure and rehabilitation activities i.e. in the evaluation of 'moonscaping' (Walker 1987), a technique for mine waste rehabilitation of large landforms at angle of repose, tipped off ridgelines. In 2017 a team of Anglo American's South Africa rehabilitation representatives benchmarked moonscaping in the Pilbara (Lacy et al. 2018). The quality of rehabilitation and stability given 20-30 years since application, appeared comparable with surrounding areas, landforms appeared stable, vegetation (grass and trees) establishing, particularly if some fine wastes/topsoil were added to the coarse waste rock surface prior to treatment, the team were satisfied by looking at field tests of the concept to use the method at their mine. 
In WA there are landforms, in various mining areas, that were notable in their evolution, and although based on limited information, may provide an insight to practitioners of the future, not only for further study, but to inform and learn from both historical and current closure and rehabilitation activities conducted specifically at the sites. We will discuss some examples during the conference presentation. The landforms dating back to mid-1980's can be separated into three overarching themes:

1. A: were partial success was achieved, with very limited design.

2. B: those that were re-built with intervention post construction.

3. C: landforms that were designed from original concepts, attaining a high rehabilitation standard, and are appearing to stand the test of time.

\section{Future direction}

The historical science of geomorphology, brings us back to the future, as it provides the best framework for understanding and quantifying stability and changes in erosion and sedimentation, which is the root of the wastes' release to the environment from disturbed mine sites (Stiller et al. 1984). There is an ongoing need to integrate rehabilitation knowledge and the science of restoration ecology, with the process of landform creation and closure, and I believe that to be around the science of geomorphology.

Evidence of advanced work to consider waste landform design and site drainage was evident in the Australian coal industry with the work of Hannan in a specific mine rehabilitation handbook (Hannan 1984), followed some time later by the more generic work 'Landform Design for Rehabilitation' that exposed the mining industry to use of CivilCAD/ and Autocad for tools for design, survey control and earthworks. This guide, applying the concepts of geomorphic design in "mirroring stable natural landforms, where watercourses become progressively steeper as one moves upstream" (Environment Protection Agency 1998, p. 20), with the goal to replicate the patterns and complexity that landforms have in natural catchments, a topic extensively studied by geomorphology for around 150 years (Hancock et al. 2019, p. 141).

In 2006 these concepts in recognition of the natural systems were reinforced within that guide, i.e. "mined landforms should mimic natural landforms as much as possible" and "Natural hillslopes are protected from erosion by rock armouring, cemented cap rock and vegetation, and that mine waste rehabilitation earthworks should aim to reconstruct similar distributions of slope angles, slope lengths, vegetation patterns to those that were in place prior to mining" (Department of Industry Tourism and Resources 2006, p. 33). It was recommended by those authors 'that fluvial geomorphic mine waste rehabilitation design principles, such as those used by BHP Billiton at La Plata and San Juan coal mines...should be employed in preference to linear engineering design principles'.

Why there was no reference in the Australia guideline (Department of Industry Tourism and Resources 2006) to the fact that La Plata Mine was utilising the GeoFluv ${ }^{\mathrm{TM}}$ fluvial geomorphic reclamation design method from 1999 to 2008 (Bugosh \& Epp 2019) remains a puzzle. There was clearly evidence of success in the application of geomorphic design tools in the USA. Over 15 years many papers can be found in the proceedings of the American Society of Mine Reclamation (https://www.asmr.us/Publications/Conference-Proceedings) and elsewhere in USA journals, reporting on the use of tools such as SurvCADD ${ }^{\mathrm{TM}}$ (Carlson Software) and Carlson Regrade (Toy \& Chuse 2005; Zapico et al. 2018; Hancock et al. 2019). This omission remained the same with the next update of Mine Rehabilitation (Department of Industry, Innovation and Science 2016, p. 19-26) with no mention of the geomorphic or fluvial design concepts, rather continual discussion of LEM modelling (Department of Industry, Innovation and Science 2016, pp. 20-23), when in fact it's quite clear that in many parts of the world the use of various geomorphic design tools for landform design was well-advanced.

As pointed out by Williams (2014) in effect, natural landscapes are a three-dimensional arrangement of drainage networks and convex/concave slopes, and when it comes to landform design. Figure 1 shows a schematic that contrasts the differences between the commonly engineered design ubiquitous in mining, and an alternative landform design that takes into account the pre-existing drainage lines and natural shapes (Williams 2014), and suggests geomorphic understanding is the natural progression in design. 

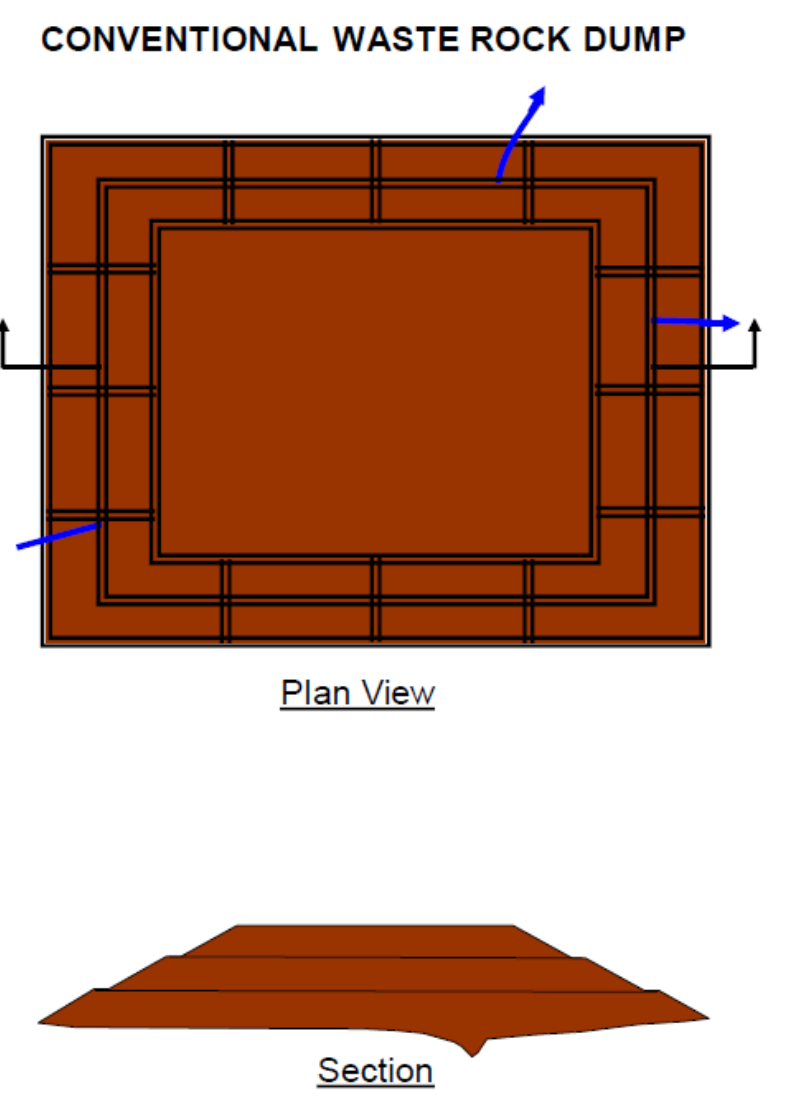

\section{ALTERNATIVE WASTE ROCK DUMP}
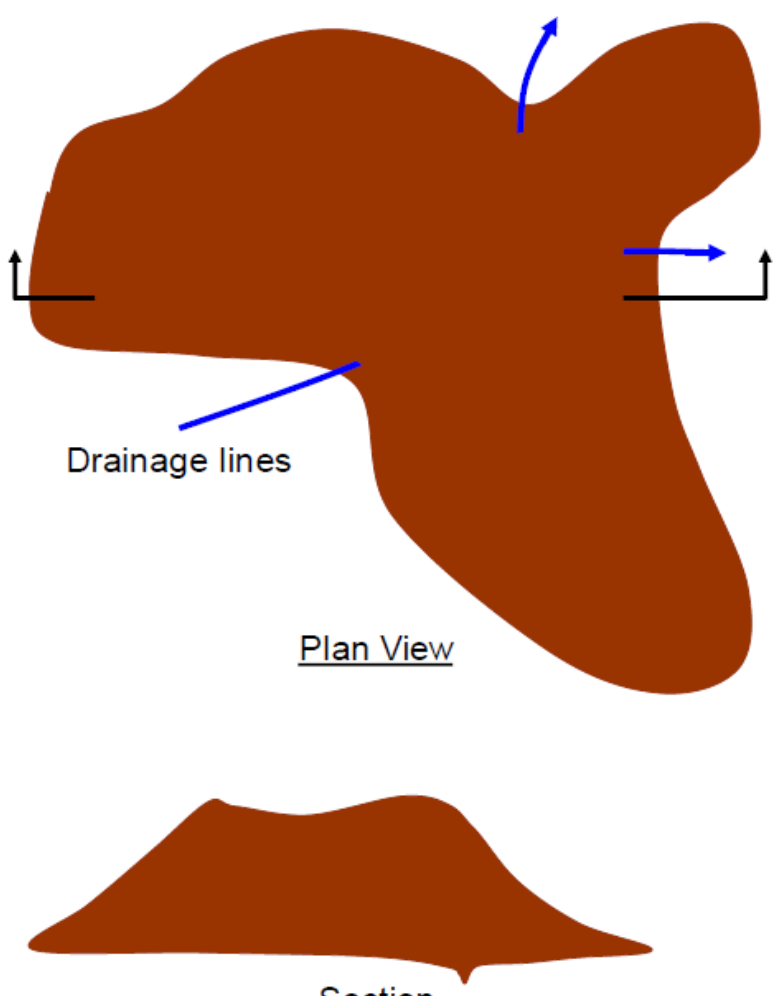

Section

Figure 1 Scheme for a geomorphic landform in comparison to current conventional form (adapted from Williams 2014)

Recently applied in Australia, the GeoFluv ${ }^{\mathrm{TM}}$ (Bugosh 2000) landform design tool was developed from longstanding geomorphic design work in USA (Stiller et al. 1980), and has been evolving since that time (Bugosh \& Eckels 2006; Bugosh et al. 2016). Essentially GeoFluv' ${ }^{\mathrm{TM}}$, is a geomorphic design method, implemented within the 'Carlson' Natural Regrade and civil computer aided design (CAD) software product. The tool looks to emulate local landscapes in the mine region in its design process. Hence erosion modelling of the actual mine waste using a LEM is a wise pre-requisite. As touched on previously GeoFluv ${ }^{\mathrm{TM}}$ has been in development and applied for many years, such as at the La Plata Coal mine where reclamation from 1999 to 2008 over extremely dispersive arid coal mining spoils and has been very successful (Bugosh \& Epp 2019). Recent work has been underway developing integration of a 3D design erosion model to bring the LEM SIBERIA and GeoFluv ${ }^{\mathrm{TM}}$ together, to allow the design of a stable landform (Jose Martín Duque and Greg Hancock, pers. comm., 5 May 2019) in the mine waste environment.

As these different LEM models evolved comparisons have been made to evaluate them i.e. in 2010 a comparison of WEPP, SIBERIA and RUSLE were made, and it was suggested that GeoFuv ${ }^{\mathrm{TM}}$ designs could be refined using 3D erosion models output to reduce their erosion potential (Howard et al. 2010, p. 88), that process has since occurred (Hancock et al. 2019). Roddy \& Howard (2016) later compared SIBERIA and Caesar, and later Howard $\left(2018\right.$, p. 4) tabulated and compared 4 LEM models, with GeoFluv ${ }^{\mathrm{TM}}$, which is unusual, as they are incomparable. GeoFluv ${ }^{\mathrm{TM}}$ (a design tool) bares little comparison with the 4 LEM RUSLE (I Dimensional) WEPP, (2D), CAESAR and SIBERIA (3D) models. Clearly some confusion exists regarding the differences and application of landform erosion modelling software versus design tools, however with further experience application the matters will be resolved.

At the Drayton mine, Hancock et al. (2019) describes the combined use of SIBERIA and GeoFluv ${ }^{\mathrm{TM}}$ for obtaining optimal mine rehabilitation outcomes (evaluated in terms of erosional stability). Both tools share key common characteristics: (1) a catchment scale approach; (2) the combined use of hillslope and fluvial geomorphic principles and algorithms; (3) and the concept of maturity in landforms and landscapes (again, 
at a catchment scale). Despite this optimisation, the joint use of SIBERIA and GeoFluv ${ }^{\mathrm{TM}}$ is only starting to be adopted as best practice in the Australian environment (Landloch 2010; Waygood 2014; Kelder 2016; as cited in Hancock et al. 2019 p. 141), and more so in eastern Australia, were Hamonet (2018) provided compelling reasons for use of GeoFluv ${ }^{\mathrm{TM}}$ at Glencore' Mangoola mine:

- To develop appropriate dumps and ramps to produce a natural landform.

- Better water quality through stability of landform, due to reduced erosion potential.

- Reduced maintenance due to lack of specific water management structures.

- Increased biodiversity due to a range of topographic relief.

- Appropriate planning for vegetation communities and habitat augmentation for fauna.

- More visual appeal in landform which, over time, should not look like mine rehabilitation.

The future direction for the industry is toward the consistent use of effective landform design processes, as these have evolved to acknowledge reclamation and closure, and mining professionals are listing those processes within design factors i.e.; systems to reduce and eliminate loses and contamination, considerations for reclamation and closure, to maintain long-term stability, erosion control and to avoid re-working and handling costs (Piteau; Sommerville \& Heyes as cited in Ortiz 2017).

\section{Conclusion}

The industry continues to strive toward stable, non-polluting, rehabilitated landforms that meet a final land use, and reflects the requirements of the community and regulators. This review demonstrates that mine landform design, construction, rehabilitation and closure, has advanced considerably within the WA mining industry, and reflects a worldwide trend.

Over this 40-year period, changes are most apparent in:

- The influences driving landform design improvement.

- Awareness of responsibility with a more holistic vision for mine landforms.

- Technological capability in many facets across the industry.

- Capacity building occurred in the mining and consulting workforce.

- Time, and how it challenges all aspect of landform design and closure thinking.

It could be postulated that a desire to achieve a landform design vision i.e. "when landform construction and rehabilitation of the mine waste material drives the mine planning and mining process" as suggested by Jose Martín Duque (pers. comm., November 2018), has been developing in WA. The initial steps are evident in some of the early landform design work, is increasing in WA and across Australia. The process of landform design and rehabilitation is multidimensional, and we do have a handful of historical sites that can be called upon in WA as analogues, and as guides to confirm what has, and has not, worked in landform design despite our initial lack of experience, have progressed to a reasonable state in early landform evolution.

The review suggests that despite the industry's desire to proceed well, we are yet to take full advantage of the suite of geomorphic landform design tools available by application during mine planning. The future presents us with further work on effective application of landform design with these tools, and matching of the correct Landform Model to an appropriate tool. The industry and regulators are looking to design in the solutions to the landform problems that we have discussed in this paper, and evident from historical approaches to mine waste management in WA. The work will be of value to an industry that is looking to its reputation and responsibilities in the longer term, in seeking to leave a positive legacy of post-closure mine landforms in WA, across Australia, and globally. 


\section{Acknowledgement}

The author thanks Professors Jose Martín Duque and Greg Hancock for assisting with the preparation of paper.

\section{References}

Australian and New Zealand Minerals and Energy Council \& Minerals Council of Australia 2000, Strategic Framework for Mine Closure, Canberra.

Archer, J 1990, 'Planning Dump Management - Including Erosion Control/Stability', Proceedings of the Workshop on Environmental Management in the Goldfields, The Chamber of Mines Western Australia Inc., Kalgoorlie.

Ashby, A \& Van Etten, E 2016, 'Exploration of gold mines in care and maintenance', Proceedings of the Workshop on Rehabilitation of Arid and Semi-arid Areas, Goldfields Land Rehabilitation Group, Boulder.

Beiha-Malen, Y, Friedel, A, Birch, B, Kentwell, J \& Moiler, K 2012 'Selecting Appropriate Vegetation-Based Completion Criteria for Mine Site Rehabilitation', Proceedings of the Workshop on Rehabilitation of Arid and Semi-arid Areas, Goldfields Environmental Management Group, Kalgoorlie-Boulder, pp 138-155.

Bellamy, S 2016, Western Australia's Abandoned Mines Program, Workshop on Rehabilitation of Arid and Semi-arid Areas, Goldfields Environmental Management Group, Boulder.

Berger, A 2003, Reclaiming the American West, Princeton Architectural Press, New York, p. 15.

Blandford, DC 1994, 'Physical Characterisation of Mine Material and Engineering Requirements to Provide Long Term Stability of Open Pits and Waste Dumps', Proceedings of the Workshop on Rehabilitation of Arid and Semi-arid Areas, Goldfields Land Rehabilitation Group, Boulder, pp. 63-68.

Bradley, G 1996, 'Waste Rock Dump Design at Kalgoorlie Consolidated Gold Mines', Proceedings of the Post-Mining Landform Stability and Design Workshop, Australian Centre for Minesite Rehabilitation Research, Queensland.

Burnside, D 1987, 'Soil Handling and Management', Proceedings of the Workshop on Environmental Management in the Goldfields, The Chamber of Mines Western Australia Inc., Kalgoorlie.

Bugosh, N 2000, 'Fluvial Geomorphic Principles Applied to Mined Land Reclamation', Proceedings of the Alternatives to Gradient Terraces Workshop, Office of Surface Mining, Farmington.

Bugosh, N \& Eckels, R 2006, 'Restoring Erosional Features in the Desert', Coal Age 111, vol. 3, pp. 30-32.

Bugosh, N \& Epp, E 2019, 'Evaluating Sediment Production from Native and Fluvial Geomorphic Reclamation Watersheds at La Plata Mine', Catena, vol. 174, pp. 383-398.

Bugosh, N, Martín-Duque, JF \& Eckels, R 2016, 'The GeoFluv Method for Mining Reclamation: Why and How it is Applicable to Closure Plans in Chile', in J Wiertz \& D Priscu (eds), Proceedings of the First International Congress on Planning for Closure of Mining Operations, Gecamin, Santiago.

Campbell, G 1994, 'Geochemical Characterisation of Mine Overburden and implications for Rehabilitation', Proceedings of the Workshop on Environmental Management in Arid and Semi-Arid Areas, Goldfields Land Rehabilitation Group, Kalgoorlie, pp. 59-62.

Campbell, G 2004, Store/Release Covers in the Australian Outback: A Review, Seminar Notes, Mine Closure - Towards Sustainable Outcomes, Australian Centre for Geomechanics, Perth.

Campbell, G 2006, 'Acid Formation Potential of Mine-Wastes: Sampling, Testwork and Interpretation Approaches for the WA Goldfields', Proceedings of the Workshop on Environmental Management, Goldfields Environmental Management Group, Kalgoorlie-Boulder, pp. 147-154.

Cannon, M 1996, 'Safe Stable and Non-Erodible?', Proceedings of the Workshop on Environmental Management in Arid and SemiArid Areas, Goldfields Land Rehabilitation Group, Kalgoorlie, pp. 33-124.

Cohen S, Willgoose GR \& Hancock G 2009, 'The MARM spatially distributed soil evolution model: a computationally efficient modelling framework and analysis of hillslope soil surface organization', Journal of Geophysical Research, vol. 114, F03001.

Department of Industry, Innovation and Science 2016, Leading Practice Handbook: Mine Rehabilitation, Commonwealth of Australia, https://www.industry.gov.au/data-and-publications/leading-practice-handbook-mine-rehabilitation

Department of Industry Tourism and Resources 2006, Leading Practice Sustainable Development Program for the Mining Industry, Commonwealth of Australia.

Department of Industry and Resources 1996, 'Guidelines for Mining in Arid Environments'. Government of Western Australia, Mining Operations Division, East Perth.

Department of Mines and Petroleum 2001, Waste Rock Dumps, Environmental Notes on Mining, Government of Western Australia, Environment Division, East Perth.

Department of Mines and Petroleum \& Environmental Protection Authority 2011, Guidelines for preparation of Mine Closure Plans, Government of Western Australia, Environment Division, East Perth, p. 4.

Environment Protection Agency Australia 1998, 'Landform Design for Rehabilitation', in K Lindbeck \& J Hannan (eds), Best Practice Environmental Management in Mining, Department of Environment, Canberra.

Evans KG \& Riley, SJ 1994, 'Planning stable post-mining landforms: the application of erosion modelling', Proceedings of the AusIMM Annual Conference, Darwin NT, Parkville, pp. 411-414.

Fahey, M 1994, Material properties, Tailings Management and Rehabilitation short course, Australian Centre for Geomechanics, Perth, pp. 3-16. 
Farrell, T 2006, 'Materials Characterisation at Mine Sites; Some Field Experiences', Proceedings of the Workshop on Environmental Management Environmental Management Group, Kalgoorlie-Boulder, pp. 155-162.

File, T, Lacy, H, Biggs, B \& Friedel, A 2010, 'Ecosystem Function Analysis: Measuring and Monitoring for Mine Closure and Completion in Australia and Abroad 1994 to 2008', Proceedings of the Workshop on Environmental Management Environmental Management Group, Kalgoorlie - Boulder, pp. 195-210.

Fletcher, M, Malcolm, C, Petersen, A, Jennings, B \& Burnside, DT 1989, 'Abatement of dust in the Kalgoorlie region by revegetation of overburden stockpiles', Report: No 44, Minerals and Energy Research Institute of Western Australia, East Perth, pp. 2-66.

Fourie, AB (ed.) 2008, 'Rock Dumps 2008', Proceedings of the First International Seminar on the Management of Rock Dumps, Stockpiles and Heap Leach Pads, Australian Centre for Geomechanics, Perth.

Fourie, AB \& Jewell, R (eds) 2010, 'Mine Waste 2010', Proceedings of the First International Seminar on the Reduction of Risk in the Management of Tailings and Mine Waste, Australian Centre for Geomechanics, Perth.

Franklin, P, Reid, A, Olsen, N, Peters, S, De Klerk, N, Brims, F, ... \& Musk A 2016, 'Incidence of malignant mesothelioma in Aboriginal people in Western Australia', Journal Indigenous Health, Australian and New Zealand Journal of Public Health, vol. 40, no. 4, pp. 383-387.

Franks, DM 2015, 'Mining Sustainability and the agents of change', Mountain Movers, Routledge, London.

Gilkes, RJ 1998, 'Constructing Sustainable Soils from Mining Waste: Principals \& Some W.A. Examples', Proceedings of the Workshop on Rehabilitation of Arid and Semi-arid Areas, Goldfields Land Rehabilitation Group, Boulder, pp. 63-72.

Greenwald, N 1987, 'Environmental Aspects of Mine Closure', Proceedings of the Workshop on Environmental Management in the Goldfields, The Chamber of Mines Western Australia Inc., Kalgoorlie.

Gregory, S, Mackenzie, S \& Smedley, E, 2014, 'Challenging the Development of Closure Criteria to enhance the Measurement of Closure Performance', Proceedings of the Workshop on Environmental Management, Goldfields Environmental Management Group, Kalgoorlie-Boulder.

Hancock, GR, Loch, RJ \& Willgoose, GR 2003, 'The design of postmining landscapes using geomorphic principles', Earth Surface Processes and Landforms, vol. 28, pp. 1097-1110.

Hancock, GR, Martín-Duque, JF \& Willgoose, GR 2019, 'Geomorphic design and modelling at catchment scale for best mine rehabilitation - The Drayton mine example (NSW, Australia)', Environmental Modelling and Software. vol. 114, pp. $140-151$.

Hancock, GR \& Willgoose, GR 2017, 'Sustainable mine rehabilitation - 25 Years of the SIBERIA landform evolution and long-term erosion model', From Start to Finish: Life-of-mine Perspective, Australian Institute of Mining and Metallurgy, Carlton, pp. 371-381.

Hancock, GR, Willgoose, GR, Evans, KG, Moliere, DR \& Saynor, MJ 2000, 'Medium term erosion simulation of an abandoned mine site using the SIBERIA landscape evolution model', Australian Journal of Soil Research, vol. 38, pp. 249-263.

Hancock, S 2019, 'Social licence to operate: regaining community trust', Aus/MM Bulletin, https://www.ausimmbulletin.com/feature/social-licence-operate-regaining-community-trust/

Hannan, JC 1984, Mine Rehabilitation: A Handbook for the Coal Mining Industry, 2nd edn, NSW Coal Association, Sydney.

Hamonet, A 2018, 'Glencore's Approach to Rehabilitation, AusIMM Bulletin, https://www.ausimmbulletin.com/feature/glencoresapproach-rehabilitation/

Haymont, R 2018, 'Erosion Modelling and Landform Design', Proceedings of the Workshop on Environmental Management, Goldfields Environmental Management Group, Kalgoorlie-Boulder.

Haymont, R \& Campbell, G 2008, 'Soil covers and capping monitoring techniques: an account of on-site experiences', Proceedings of the Workshop on Environmental Management, Goldfields Environmental Management Group, Kalgoorlie-Boulder, pp. 63-70.

Heaney, R 2016, 'How Western Australia is handling the end of the mining boom', The Conversation, https://theconversation.com/how-western-australia-is-handling-the-end-of-the-mining-boom-69217

Howard 2014, 'Surface Roughness and its influence on Erosion of Waste Dump Batters', Proceedings of the Workshop on Environmental Management, Goldfields Environmental Management Group, Kalgoorlie-Boulder.

Howard, EJ, Loch, RJ \& Vacher, CA 2010 'Evolution of landform Design Concepts', in AB Fourie \& R Jewell (eds), Proceedings of the First International Seminar on the Reduction of Risk in the Management of Tailings and Mine Waste, Australian Centre for Geomechanics, Perth, pp. 83-89.

Howard, E 2018, 'Integrating Erosion Prediction into Landform Designs for Rehabilitation and Closure Planning', Planning for Closure, 2nd International Conference on Planning for Closure of Mining Operations, Gecamin, Santiago.

International Council of Mining and Metals 2019, Integrated Mine Closure: Good Practice Guide, 2nd edn, London.

Jasper, D 1994, 'Defining and achieving adequate activity of beneficial soil microbes in revegetated mine soils, Proceedings of the Workshop on Environmental Management in Arid and Semi-Arid Areas, Goldfields Land Rehabilitation Group, Kalgoorlie, pp. 85-89.

Jasper, D \& Braimbridge, M 2006, 'Waste Characterisation for Optimal Landforms', Proceedings of the Workshop on Environmental Management, Goldfields Environmental Management Group, Kalgoorlie-Boulder, pp. 128-144.

Jasper, DA, Braimbridge, M, Lacy, HWB \& Russell, M 2006, 'Integrating waste characterisation into landform design for low-risk and low-cost mine closure', in A Fourie \& M Tibbett (eds), Proceedings First International Seminar on Mine Closure, Australian Centre for Geomechanics, Perth, pp. 539-548.

Jasper, DA, Lacy, HWB, Russell, M \& Braimbridge, M 2012, 'Landform planning: using science and economics to reduce operating costs and closure risk', in A Fourie \& M Tibbett (eds), Proceedings of the Seventh International Conference on Mine Closure, Australian Centre for Geomechanics, Perth, pp. 13-22. 
Jennings, B, Barrett-Lennard, EG, Hillman, BG \& Emrose, M 1993, Mine Waste Management in Arid Areas, Report No 110, Minerals and Energy Research Institute of Western Australia, pp. 36-42.

Jewell, R 2005, 'Introduction', in R Jewell \& AB Fourie (eds), Paste and Thickened Tailings - A Guide, 2nd edn, Australian Centre for Geomechanics, Perth.

Jones, H 2008, 'The Metamorphism of Dumps into Hills', in AB Fourie (ed.), Proceedings of the First International Seminar on the Management of Rock Dumps, Stockpiles and Heap Leach Pads, Australian Centre for Geomechanics, Perth, pp. 267-275.

Kelder, I \& Waygood, C 2016, 'Integrating the use of natural analogues and erosion modelling', in A Fourie \& M Tibbett (eds), Proceedings of the 11th International Conference on Mine Closure, Australian Centre for Geomechanics, Perth.

Lacy, HWB 1997, 'Environmental management of gold mining operations in proximity to a town site in the arid rangelands of Western Australia, Dominion Gold Operations, Meekatharra, 1989-1996', Proceedings of the Annual Environmental Workshop, Australian Minerals Industry Conference, Adelaide.

Lacy, HWB 1998, 'Waste landforms in arid environments: water retaining waste landforms and smoothing the structure to match the environment', Proceedings of the Workshop on Environmental Management in Arid and Semi-Arid Areas, Goldfields Land Rehabilitation Group, Kalgoorlie, pp. 73-82.

Lacy, HWB \& Haymont, R 2006, 'Cooperative Partnership and Innovation in Planning and Execution of the Decommissioning of the Mt McClure Gold Project', Proceedings of the Workshop on Environmental Management, Goldfields Environmental Management Group, Kalgoorlie-Boulder.

Lacy, HWB \& Barnes, KL 2006, 'Tailings Storage Facilities - Decommissioning Planning is Vital for Successful Closure', in A Fourie \& M Tibbett (eds), Proceedings of First International Seminar on Mine Closure, Australian Centre for Geomechanics, Perth, pp. 139-148.

Lacy, H \& Lane J 2007, Integrated Landforms and Waste Stream Management, Planning for Mine Closure Seminar, Australian Centre for Geomechanics, Perth, pp. 1-13.

Lacy, HWB, Grant, CD, Lambrechts, J \& Voigt, W 2018 'Benchmarking; Bringing the lessons from the past into the future', in C Drebenstedt, F Von Bismarck, AB Fourie \& M Tibbett (eds), Proceedings of the 12th International Seminar on Mine Closure, Technical University Bergakademie Freiberg, Leipzig.

Lacy, HWB \& Grant, CG 2018, 'Landform Rehabilitation Evolution and Benchmarking; The Influence of the GEMG Environmental Management Workshop', Proceedings of the Workshop on Environmental Management, Goldfields Environmental Management Group, Kalgoorlie-Boulder.

Lane, JC 1998, 'Innovative approaches to tailings disposal', Proceedings of the Future Directions in Tailings Management Australian Centre for Mining Environmental Research Workshop, Kenmore.

Lane, JC 2004 Integrated landforms - an alternative approach to tailings storage, Mine Closure - Towards Sustainable Outcomes, Australian Centre for Geomechanics, Perth.

Landloch Pty Ltd, 2006, Generic Concave Slope Profiles for Constructed landforms, Murrin Nickel Operations, unpublished.

Landloch Pty Ltd, 2010, Sustainable Landscape Design for Coal Mine, Rehabilitation, Project No 18024, Report Prepared for ACARP.

Law, J 1992, 'Erosion control strategies on areas disturbed by mining', Proceedings of the Workshop on Rehabilitation of Arid and Semi-arid Areas, Goldfields Land Rehabilitation Group, Boulder.

Leidich, T, Lacy, H \& Van Zyl, M 2014, 'Application of design concepts and engineering controls necessary to deliver well designed and rehabilitated landforms', Proceedings of the Life-of-Mine Conference, Australasian Institute of Mining and Metallurgy, Carlton.

Lindbeck, K 1992, 'Research priorities and funding for minesite rehabilitation', Proceedings of the Workshop on Rehabilitation of Arid and Semi-Arid Areas, Goldfields Land Rehabilitation Group, Boulder, pp. 117-118.

Loch, R \& Willgoose G 2000, 'Rehabilitated Landforms Designing for Stability', Proceedings of the Workshop on Rehabilitation of Arid and Semi-Arid Areas, Goldfields Land Rehabilitation Group, Boulder, pp. 39-44.

Loch, RJ, Vacher, CA \& Lowe, SM 2008, 'Topsoil Organic Carbon and Nutrients for Waste Dump Rehabilitation', Proceedings of the Workshop on Rehabilitation of Arid and Semi-arid Areas, Goldfields Land Rehabilitation Group, Boulder, pp. 102-108.

Loney, B 1998, 'Integrating Waste Dumps into the Landscape - a Case Study', Proceedings of the Workshop on Rehabilitation of Arid and Semi-arid Areas, Goldfields Land Rehabilitation Group, Boulder, pp. 45-50.

Mabin, M 2014, 'Geomorphic Design for Mine Development, Expansion and Closure', Proceedings of the Workshop on Environmental Management, Goldfields Environmental Management Group, Kalgoorlie-Boulder.

McPhail, G \& Wilkinson, D 2004, 'Waste Rock Dump Decommissioning at Mines in Northern Western Australia', Proceedings of the Workshop on Environmental Management 2004, Goldfields Environmental Management Group, Kalgoorlie-Boulder.

Mifsud, JA, Ryan-Reid, E \& Wealleans, M 2010, 'Waste rock dump rehabilitation to a new level - Telfer WD13 constructed mesa landform', in AB Fourie \& RJ Jewell (eds), Proceedings of the First International Seminar on the Reduction of Risk in the Management of Tailings and Mine Waste, Australian Centre for Geomechanics, Perth, pp. 103-117.

Mohensen, A 1992, 'Developing Completion Criteria associated with Rehabilitation of Gold Mine ands', Proceedings of the Workshop on Rehabilitation of Arid and Semi-arid Areas, Goldfields Land Rehabilitation Group, Boulder.

Office of Surface Mining Reclamation and Enforcement 1977, Public Law 95-87, Surface Mining Control and Reclamation Act of 1977, U.S. Department of the Interior, unofficial compilation, https://www.osmre.gov//rg/docs/SMCRA.pdf

Ortiz, JP 2017, 'Methodology for a dump design optimization in large-scale open pit mines', Cogent Engineering, vol. 4, https://doi.org/10.1080/23311916.2017.1387955

Osborne, J Brearley, D \& Schatral, A 1996, 'Saline gold mine waste in arid Western Australia: revegetation establishment in the absence of topsoil', Proceedings of the Workshop on Rehabilitation of Arid and Semi-arid Areas, Goldfields Land Rehabilitation Group, Boulder. 
Petersen, A 1987, 'Waste Management and Stabilisation', Proceedings of the Workshop on Environmental Management in the Goldfields, The Chamber of Mines Western Australia Inc., Kalgoorlie.

Roddy, B \& Howard, E 2016, 'A Comparisons of Different Landscape Evolution Models for Waste Landform Closure Design', Proceedings of the Workshop on Environmental Management, Goldfields Environmental Management Group, KalgoorlieBoulder.

Russell, M 2008, 'So you want to have the best possible waste rock dump', in A Fourie (ed.), Proceedings of the First International Seminar on the Management of Rock Dumps, Stockpiles and Heap Leach Pads, Australian Centre for Geomechanics, Perth.

Russell, M \& Lacy, HWB 2015, 'Imperatives of Good Landform Design: adding value, reducing mine impacts and operating costs through innovative waste material management, engineering design and operational action', in AB Fourie, $M$ Tibbett, $L$ Sawatsky \& D van Zyl (eds,), Proceedings of the Seventh International Conference on Mine Closure, InfoMine Inc., Vancouver.

Sholtz, G 1996, 'Soil and Landform Associations of the Eastern Goldfields' Proceedings of the Workshop on Environmental Management in Arid and Semi-Arid Areas, Goldfields Land Rehabilitation Group, Kalgoorlie, pp. 177-124.

Sperring, P \& Lacy, H 2001, Mining Proposal for Challenger Mining Project, Submitted to PIRSA by Dominion Mining Ltd.

Stoneman, T 1994, 'Goldfield soils - development, characteristics and relevance to mine rehabilitation', Proceedings of the Workshop on Rehabilitation of Arid and Semi-arid Areas, Goldfields Land Rehabilitation Group, Boulder.

Stiller, D, Zimpfer, GL \& Bishop, M 1980, 'Application of Geomorphic Principals to Surface Mine Reclamation in the Semi-arid West', Journal Soil and Water Conservation, pp. 274-277.

Swain, D, Stewart, L, Jeanes, B \& Lacy, H 2004, 'Landforms Containing Dispersive Soils: Actions to Understand, Actions to Manage and Mitigate at Placer's Kundana Project', Proceedings of the Workshop on Environmental Management, Goldfields Environmental Management Group, Kalgoorlie-Boulder, pp. 150-162.

Thompson, S \& Thompson, G, 2012, 'Mine Closure; The Forgotten Fauna', Proceedings of the Workshop on Environmental Management, Goldfields Environmental Management Group, Kalgoorlie-Boulder, pp. 254-267.

Toy, TJ \& Chuse, WR 2005, 'Topographic reconstruction: a geomorphic approach', Ecological Engineering, vol. 4, pp. 29-35.

Walker, KJ 1987, 'Moonscaping', Proceedings of the Workshop on Environmental Management in the Goldfields, The Chamber of Mines Western Australia Inc., Kalgoorlie.

Walsh, T 2014, 'Progressive Approach to Growth Medium Mining', Proceedings of the Workshop on Environmental Management, Goldfields Environmental Management Group, Kalgoorlie-Boulder.

Waygood C, 2014, 'Adaptative landform design for closure', in I Weiersbye (ed.), Proceedings of the 9th International Conference on Mine Closure, University of the Witwatersrand, Johannesburg, p. 12.

Welivitiya, WDP, Willgoose, GR, Hancock, GR \& Cohen, S 2016, 'Exploring the sensitivity on a soil area-slope-grading relationship to changes in process parameters using a pedogenesis model', Earth Surface Dynamics, vol. 4, pp. 607-625.

Williams, A \& Pratt, A 2008, 'Growth Response to Phosphorus of Selected Native Goldfields Plants - Implications to Revegetation and Fertiliser Requirements', Proceedings of the Workshop on Environmental Management, Goldfields Environmental Management Group, Kalgoorlie-Boulder, pp. 94-101.

Williams, D 2014, 'Mine planning for the final landform', Proceedings of the 5th International Mining and Industrial Waste Management Conference, Rustenburg, pp. 1-52.

Willgoose, GR 1989, A Physically Based Channel Network and Catchment Evolution Model, PhD thesis, Massachusetts Institute of Technology, Boston.

Willgoose, GR 2005, 'Mathematical modelling of whole-landscape evolution', Annual Review of Earth and Planetary Sciences, vol. 33, pp. 443-459.

Willgoose, GR 2012, User Manual for SIBERIA, version 8.33 (online). pp. 115, http://www.telluricresearch.com/ siberia_8.33_manual.pdf

Woolard, C \& Valent, M 1992, 'Mullock dump modelling: initiatives at Kambalda, Western Australia', Proceedings of the Workshop on Rehabilitation of Arid and Semi-arid Areas, Goldfields Land Rehabilitation Group, Boulder.

Zapicoa, I, Martín Duque JF, Bugosh, N, Laronne, JB, Ortega, A, Molina, A, \& Castillo LZ 2018, 'Geomorphic reclamation for reestablishment of landform stability at a watershed scale in mined sites: the Alto Tajo Natural Park, Spain', Ecological Engineering, vol. 111, pp. 100-116. 